\title{
Pemberdayaan Paguyuban Nelayan Dalam Pemulihan Ekonomi Keluarga Nelayan Pasca Tsunami dan Memasuki Masa Kenormalan Baru Pandemi Covid 19 di Desa Teluk Kecamatan Labuan, Kabupaten Pandeglang Bambang Dwi Suseno*1, Pramudianto ${ }^{2}$, Salaf Udin ${ }^{3}$ \\ 1,2, Program Studi Magister Manajemen Universitas Bina Bangsa, ${ }^{3}$ Mahasiswa Magister Manajemen Universitas Bina Bangsa \\ Corresponding author, e-mail: bambangds_mm@binabangsa.ac.id ${ }^{1 *}$, pram.coach@gmail.com² salapudin606@gmail.com ${ }^{3}$
}

\begin{abstract}
Teluk Village, Labuan Subdistrict, after the tsunami disaster caused the economy of Teluk Village residents to deteriorate, where the boats that were used as fishermen's transportation to go to sea were mostly destroyed and some even sank. The deterioration due to the tsunami has not yet been completed, exacerbated by the Covid-19 pandemic since March 2020, and until the end of December 2020 there has been no visible recovery in economic activity for fishermen to support their daily lives. Community service is an activity of applying the results of research or studies which are then applied to overcome problems in the community related to efforts to restore the family's economy after the tsunami and the new normality of the Covid-19 pandemic. Teluk Village has business activities related to fishing, auction, fish preservation and fish distribution. The potential is good to be used as entrepreneurial development, especially salted fish processing to become a superior in this village. This is a great opportunity to open home industry-based entrepreneurs which, if facilitated by the village through BUMDes, is very likely to make this village have its own icon. However, packaging, good processing methods, market place and individual and institutional capacity building of BUMDes need continuous assistance. and diversification of community economic resources
\end{abstract}

Keywords: Empowerment, Fishermen Association, Economic Recovery, New Normality of the Covid19 Pandemic

\section{Abstrak}

Desa Teluk Kecamatan Labuan pasca terjadinya bencana tsunami tersebut mengakibatkan perekonomian warga desa teluk menjadi terpuruk, dimana kapal kapal yang menjadi transportasi nelayan untuk melaut sebagian besar hancur bahkan sebagian ada yang tenggelam. Belum selesai keterpurukan akibat tsunami, diperparah oleh pandemic covid-19 sejak Maret 2020, dan sampai akhir Desember 2020 belum nampak pemulihan aktivitas ekonomi bagi para nelayan dalam menopang kehidupan sehari-hari. Pengabdian kepada masyarakat adalah suatu kegiatan penerapan hasil riset atau kajian yang kemudian diterapkan untuk mengatasi problematik dimasyarakat terkait dengan upaya pemulihan ekonomi keluarga pasca tsunami dan masa kenormalan baru pandemic covid-19. Desa Teluk ini memeiliki aktivitas usaha yang terkait dengan penangkapan ikan, pelelangan, pengawetan ikan dan distribusi ikan. Potensi bagus untuk dijadikan pengembangan wirausaha, terutama pengolahan ikan asin menjadi unggulan di desa ini. Hal ini menjadi peluang besar untuk membuka wirausaha berbasis home industri yang jika difasilitasi oleh desa melalui BUMDes, sangat mungkin menjadikan desa ini mempunyai ikon tersendiri.Namun demikian kemasan, cara pengolahna yang baik, market place dan peningkatan kapasitas individu dan kelembagaan BUMDes perlu pendampingan yang berkesinambungan dan diversifikasi sumber ekonomi masyarakat

Kata kunci: Pemberdayaan, Paguyuban Nelayan, Pemulihan Ekonomi, Masa Kenormalan Baru Pandemi Covid-19 


\section{PENDAHULUAN}

Desa Teluk merupakan salah satu desa yang terletak di wilayah Kecamatan Labuan Kabupaten Pandeglang, Kecamatan Labuan berada disebelah Barat Kabupaten Pandeglang yang berjarak sekitar $41 \mathrm{~km}$ dari Pusat Kota Pandeglang. Kecamatan Labuan memiliki luas 15,65 km2, sedangkan Desa Teluk memiliki luas 1,79 km2 atau sekitar $12,59 \%$ dari luas Kecamatan. Desa Teluk terdiri dari 16 Kampung yaitu, Kampung Karet, Kampung Karang Tenggang, Kampung Umbul Tanjung, Kampung Teluk Tengah, Kampung Pelelangan, Kampung Tanjung Sari, Kampung Cipunten Agung, Kampung Lebak Tanjung, Kampung Cicadas, Kampung Citanggok, Kampung Pasir Tanjung, Kampung Perikanan I, Kampung Perikanan II, Kampung Nelayan I, Kampung Nelayan II dan Kampung Badongan.

Karena Desa Teluk daerahnya dekat dengan laut sehingga sistem perekonomian Desa Teluk yaitu dibidang perikanan. Dimana sebagian besar warganya memiliki mata pencaharian sebagai Nelayan. Melalui hasil survey dan wawancara secara langsung dengan sekretaris paguyuban nelayan yang ada di desa teluk dan perangkat Desa Teluk Kecamatan Labuan dapat diidentifikasi permasalahan yang dihadapi oleh masyarakat Desa Teluk Kecamatan Labuan pasca terjadinya bencana tsunami tersebut mengakibatkan perekonomian warga desa teluk menjadi terpuruk, dimana kapal kapal yang menjadi transportasi nelayan untuk melaut sebagian besar hancur bahkan sebagian ada yang tenggelam/ hilang bahkan rumah-rumah warga yang sebagian besar masyarakat Desa Teluk memiliki rumah dipinggir pantai atau dekat dengan laut hancur terkena tsunami sehingga banyak yang kehilangan rumah mereka. Kejadian tersebut membuat para nelayan Desa Teluk susah untuk melaut dan menyebabkan pendapatan mereka berkurang, bahkan sampai saat ini masyakat masih tinggal di hunian sementara (Huntara) yang di sediakan oleh pemerintah setempat. Belum selesai keterpurukan akibat tsunami, diperparah oleh pandemic covid-19 sejak Maret 2020, dan sampai akhir Desember 2020 belum nampak pemulihan aktivitas ekonomi bagi para nelayan dalam menopang kehidupan sehari-hari.

\section{METODE}

Pengabdian kepada masyarakat adalah suatu kegiatan penerapan hasil riset atau kajian yang kemudian diterapkan untuk mengatasi problematik dimasyarakat 
terkait dengan upaya pemulihan ekonomi keluarga pasca tsunami dan masa kenormalan baru pandemic covid-19. Kegiatan ini dilakukan dengan mengembangkan ide dan hasil riset yang terkait dengan temuan yang dihadapi oleh para nelayan di Desa Teluk Kecamatan Labuan Kabupaten Pandeglang. Selanjutnya dosen dan mahasiswa berolaborasi melalui pemberdayaan paguyuban nelayan dengan melalukan pendekatan, identifikasi, profiling pihak yang berpengaruh, pemerinta desa dan pembuatan model pemberdayaan yang tepat. Mahasiswa diberikan bekal kemapuan soft skill agar dapat bersosialisasi dengan lingkungan kerja setelah menyelesaikan pendidikannyaormalan baru Pendemi Covid-19. Selanjutnya upaya pemberdayaan dilakukan dengan analisis SWOT. Pengabdian Pada Masyarakat (Pesat) dilaksanakan pada tanggal 29 Juni 2020 sampai tanggal 28 Juli 2020 bertempat di Desa Teluk Kecamatan Labuan Kabupaten Pandeglang.

\section{HASIL DAN PEMBAHASAN}

Desa Teluk merupakan salah satu desa yang terletak di wilayah Kecamatan Labuan Kabupaten Pandeglang, Kecamatan Labuan berada di sebelah Barat Kabupaten Pandeglang yang berjarak sekitar $40 \mathrm{~km}$ dari Pusat Kota Pandeglang. Kecamatan Labuan memiliki luas $15,65 \mathrm{~km}^{2}$, sedangkan Desa Teluk memiliki luas $97 \mathrm{H}$ atau sekitar 10,59\% dari luas Kecamatan. Batas Wilayah Desa Teluk adalah Sebelah Utara berbatasan dengan Desa Caringin, Sebelah Selatan berbatasan dengan Desa Labuan dan Desa Kalang Anyar, Sebelah Barat berbatasan dengan Selat Sunda, Sebelah Timur berbatasan dengan Desa Banyu Mekar. Desa Teluk terdiri dari 16 Kampung yaitu, Kampung Karet, Kampung Karang Tenggang, Kampung Umbul Tanjung, Kampung Teluk Tengah, Kampung Pelelangan, Kampung Tanjung Sari, Kampung Cipunten Agung, Kampung Lebak Tanjung, Kampung Cicadas, Kampung Citanggok, Kampung Pasir Tanjung, Kampung Perikanan I, Kampung Perikanan II, Kampung Nelayan I, Kampung Nelayan II dan Kampung Badongan. Kemudian Wilayah tersebut terbagi ke dalam 13 Rukun Warga (RW) serta 33 Rukun Tetangga (RT). Adapun Usaha Nelayan atau Perikanan terletak di Wilayah Desa Teluk Kecamatan Labuan Kabupaten Pandeglang Provinsi Banten, Letak Geografis Desa merupakan 
Pesisir (Tepi Laut) dengan Ketinggian dari permukaan laut sekitar 1 Meter dan Panjang Pantai 1-5 km.

\section{a. Warung Bina Usaha}

Salah satu potensi besar yang berada di Desa Teluk adalah penjualanan ikan. Sudah dimanfaatkan oleh BUMDes namun kita maksimalkan dengan adanya Warung Sahabat yang tentunya dikelola oleh desa ataupun BUMDes (Badan Usaha Milik Desa), dikarenakan Warung Bina Usaha ini merupakan salah satu wadah atau tempat untuk menampung hasil olahan ikan dari nelayan. Pemeberdayaan ini adalah untuk memberikan Peluang kepada masyarakat Desa Teluk dalam pengelolaan ekonomi keluarga pasca tsunami Selat Sunda dengan berdirinya Warung Bina Usaha Program Program Studi Magister Manajemen, dalam pengelolaan ini akan memberikan manfaat ekonomi yang lebih terhadap warga Desa Teluk Kecamatan Labuan Kabupaten Pendeglang.

Permasalahan yang dihadapi oleh masyarakat Desa Teluk, Kecamatan Labuan, Kabupaten Pandeglang, didapatkan melalui tahap survei dan wawancara secara langsung dengan masyarakat dan beberapa tokoh masyarakat.

Dari hasil wawancara dan survei yang dilakukan, dapat diketahui bahwa:

$>$ Adanya keinginan peningkatan Badan Usaha Milik Desa yang sedang berjalan,

> Ikut serta meramaikan Pengunjung atau wisatawan yang berkunjung ke Pelabuhan Teluk.

\section{b. Penanaman Pohon}

Desa Teluk merupakan salah satu desa yang terletak di wilayah Kecamatan Labuan Kabupaten Pandeglang, Kecamatan Labuan berada disebelah Barat Kabupaten Pandeglang yang berjarak sekitar $41 \mathrm{~km}$ dari Pusat Kota Pandeglang. Kecamatan Labuan memiliki luas 15,65 km2, sedangkan Desa Teluk memiliki luas $1,79 \mathrm{~km} 2$ atau sekitar $12,59 \%$ dari luas Kecamatan. Desa Teluk terdiri dari 16 Kampung yaitu, Kampung Karet, Kampung Karang Tenggang, Kampung Umbul Tanjung, Kampung Teluk Tengah, Kampung Pelelangan, Kampung Tanjung Sari, Kampung Cipunten Agung, Kampung Lebak Tanjung, Kampung Cicadas, Kampung Citanggok, Kampung Pasir Tanjung, Kampung Perikanan I, Kampung Perikanan II, Kampung Nelayan I, Kampung Nelayan II dan Kampung Badongan. 
Karena Desa Teluk daerahnya dekat dengan laut sehingga sistem perekonomian Desa Teluk yaitu dibidang perikanan. Dimana sebagian besar warganya memiliki mata pencaharian sebagai Nelayan.

Melalui hasil survey dan wawancara secara langsung dengan perangkat desa dan masyarakat Desa Teluk Kecamatan Labuan dapat disimpulkan permasalahan yang dihadapi oleh masyarakat Desa Teluk Kecamatan Labuan pasca terjadinya bencana tsunami tersebut mengakibatkan perekonomian warga desa teluk menjadi terpuruk, dimana rumah-rumah warga yang sebagian besar masyarakat Desa Teluk memiliki rumah dipinggir pantai atau dekat dengan laut hancur terkena tsunami sehingga banyak yang kehilangan rumah mereka.

Kejadian tersebut membuat sebagian warga Desa Teluk hingga saat ini masih tinggal di Hunian sementara (Huntara) yang di sediakan oleh pemerintah setempat.

\section{c. Ternak Ayam DOC}

Desa Teluk merupakan salah satu Kecamatan yang berada di Labuan Kabupaten Pandeglang Provinsi Banten yang terletak di sekitar pantai. Akibat dari Tsunami Selat Sunda, masyarakat banyak yang kehilangan tempat tinggal. Maka dari itu Pemerintah Kabupaten Pandeglang membuat Hunian sementara bagi para korban Tsunami untuk ditempati dengan jangka waktu 2 tahun. Bagi para masyarakat yang kehilangan pekerjaannya, Dinas Perternakan memberikan bantuan berupa 20 ekor ayam kampung KUB DOC (Day Old Chicken) melalui STIE banten untuk di rawat dan di Budidayakan guna membantu meningkatkan perekonomian masyarakat Huntara yang tidak mempunyai pekerjaan.

\section{KESIMPULAN}

Desa Teluk ini memeiliki aktivitas usaha yang terkait dengan penangkapan ikan, pelelangan, pengawetan ikan dan distribusi ikan. Potensi bagus untuk dijadikan pengembangan wirausaha, terutama pengolahan ikan asin menjadi unggulan di desa ini. Hal ini menjadi peluang besar untuk membuka wirausaha berbasis home industri yang jika difasilitasi oleh desa melalui BUMDes, sangat mungkin menjadikan desa ini mempunyai ikon tersendiri.Namun demikian kemasan, cara pengolahna yang baik, market place dan peningkatan kapasitas individu dan kelembagaan BUMDes perlu pendampingan yang berkesinambungan dan diversifikasi sumber ekonomi masyarakat 


\section{UCAPAN TERIMA KASIH}

Penulis mengucapkan terima kasih kepada Bapak Kepala dan aparatur Desa Teluk dan manajemen BUMDes yang telah sangat kooperatif bekerjasama dalam pemberdayaan melalui paguyuban nelayan dengan diversifikasi sumber ekonomi masyarakat .

\section{DAFTAR PUSTAKA}

\section{Jurnal:}

Suseno, Bambang Dwi. (2019). The Citizenship Engagement Quality Of Student In ASEAN: Will It Be Able To Realize Sustainable Economic Community Performance In The Future? International Conference on Democratisation in Southeast Asia (ICDeSA 2019), Atlantis Press, pp. 1-6.

Saefudin; Suseno, BD; Nuryanto, UW. (2019) Peran Kontrak Psikologis Sebagai Pengungkit Kinerja Pelabuhan Perikanan Nusantara Karangantu Banten, Tirtayasa Ekonomika. 14 (2), 232-246

Suseno, Bambang Dwi. (2013). Strength Wazir Capital For Growth Drivers In a Family Owned Company Natives: evidence from Indonesia (A Literature Review and Future Research Agenda), International Conference on Customer Service System and Management 2013 (ICCSSM 2013). Kuala Lumpur, Malaysia.

Brennan, M. A., \& Israel, G. D. (2008). The power of community. Community Development, 39(1), 82-97.

\section{Buku:}

BD Suseno. (2017). Bisnis Internasional dan Aplikasi Ekspor Impor, In Media, Jakarta.

Direktorat Riset dan Pengabdian Masyarakat. (2020). Panduan Penelitian Dan Pengabdian Kepada Masyarakat Edisi XIII Tahun 2020, Kemeristek/BRIN Republik Indonesia. 